\title{
ПРОЦЕС ВИПРАВЛЕННЯ ПІД ЧАС ВІДБУВАННЯ ПОКАРАННЯ У ВИДІ ПОЗБАВЛЕННЯ ВОЛІ ЯК ЕЛЕМЕНТ ПРОГРЕСИВНОЇ СИСТЕМИ: ДЕЯКІ ЗАКОНОДАВЧІ ПРОБЛЕМИ
}

Гритенко О. А.

Стаття присвячена дослідженню виправлення засуджених як елемента прогресивної системи. Автором відзначено, що складником виправлення $\epsilon$ виховний процес засуджених, який здійснюється під час відбування покарання у виді позбавлення волі. Визначені законодавчі положення, які встановлюють основні напрями виховного впливу на засуджених до позбавлення волі. Встановлено ряд законодавчих проблем, які стосуються понятійного апарату, а також відсутності деяких положень, які б визначали критерії впливу на поліпшення або погіршення становища засудженого під час відбування покарання у виді позбавлення волі.

Ключові слова: виправлення, виховний вплив, виховний процес, заходи заохочення, заходи стягнення, засуджені, прогресивна система, позбавлення волі, стимулювання.

Статья посвящена исследованию исправления осужденных как элемента прогрессивной системы. Автором отмечено, что составной исправления является воспитательный процесс осужденных, который осуществляется во время отбывания наказания в виде лишения свободы. Определены законодательные положения, устанавливающие основные направления воспитательного воздействия на осужденных к лишению свободы. Установлен ряд законодательных проблем, касающихся понятийного аппарата, а также отсутствия некоторых положений, определяющих критерии влияния на улучшение или ухудшение положения осужденного во время отбывания наказания в виде лишения свободы.

Ключевые слова: исправление, воспитательное воздействие, воспитательный процесс, меры поощрения, меры взыскания, осужденные, прогрессивная система, лишение свободы, стимулирование.

The article discussed the science of corrections the prisoners as an element of the progressive system. It is investigated that corrections of convicts are a process of positive changes that occur in his personality and create a readiness for legitimate self-managed behavior. The author noted that the disciplinary process of convicts, which is carried out while serving a sentence of imprisonment, is part of the correction. It is established that the law contains provisions on the disciplinary influence on prisoners to imprisonment, which sets out the main directions and means of achieving the goal of correcting a convicted person. Some articles had been analyzed of the Criminal Enforcement Code of Ukraine, which determine the educational influence on the convicts, namely social and educational work with the convicted to imprisonment.

Determined that the correction of a prisoner only on certain criteria, excluding certain inaccuracies or no certainty in the law can lead to serious errors.

There are identified certain legal problems related to the conceptual apparatus, as well as the absence of some provisions that would determine the provisions of the impact on the improvement or deterioration of the situation of a prisoner while serving a sentence of imprisonment. It is proved that the articals of the Criminal Enforcement Code of Ukraine, namely the improvement of them, can create the necessary grounds for their correct implementation and application in the case of determining the corrections of convicts in the form of imprisonment.

Key words: corrections, disciplinary influence, upbringing process, measures of incentives, penalties, convicts, progressive system, imprisonment, stimulus.

Постановка проблеми. Визначаючи мету покарання як виправлення засудженого - кінцевий соціальний результат, законодавецьвиходитьз того, щоїїосягнення передбачає багатогранну функціональну діяльність державних органів щодо досягнення цілей покарання.

Одним із найбільш важливих було і залишається питання про визначення цілей кримінального покарання, зокрема цілі виправлення. Усталеною думкою в доктрині кримінального права прийнято визначати мету покарання як той кінцевий результат, якого прагне досягти держава, засуджуючи винного і застосовуючи цю міру [2; 5]. Серед вчених таке визначення мети не викликає заперечень. Проте проблема змісту мети виправлення, їі ефективності продовжує залишатися одним із дискусійних питань.

Відповідно до ч. 1 ст. 6 КВК України «Виправлення і ресоціалізація засуджених та їх основні засоби» під виправленням засудженого слід розуміти процес позитивних змін, які відбуваються в його особистості та створюють у нього готовність до самокерованої правослухняної поведінки. А ч. 3 ст. 6 КВК України визначає засоби виправлення засуджених, якими $є$ встановлений порядок виконання та відбування покарання (режим), пробація, суспільно корисна праця, соціально-виховна робота, загальноосвітнє і професійно-технічне навчання, громадський вплив. Отже, зокрема, відбувається певний виховний процес засудженого під час відбування покарання у виді позбавлення волі, який проявляється в його особистості та створює у нього готовність до самокерованої правослухняної поведінки.

Виховний процес в пенітенціарних установах являє собою досить складну систему заходів, здійснюваних по відношенню до засуджених, які відбувають покарання у виді позбавлення волі. На засудженого впливають і обстановка кримінально-виконавчих установ (далі - КВУ), і настрій найближчого соціального оточення, і система його відносин, що склалася з іншими засудженими, співробітниками, близькими родичами, друзями, знайомими, і багато іншого. На нього безпосередньо і опосередковано протягом доби здійснюється вплив великої кількості джерел впливу. Практично ж 
вони можуть бути частково або повністю нейтральними, якщо вихованець залишається лише об'єктом впливу і не стає одночасно суб'єктом перевиховання, коли він починає проявляти відповідну активність у перетворенні власних природних і соціально придбаних здібностей і можливостей суспільно значущих спонукань, вчинків, дій. Прагнення особистості до самовдосконалення визначається соціально-психологічною атмосферою в КВК, всім комплексом факторів, що впливають. Система виховного впливу будується таким чином, щоб вона базувалася на широкій суспільно корисній діяльності засуджених, розвивала соціально значиму активність особистості, високу вимогливість до себе, до самоконтролю за етичною поведінкою в колективі та поза ним [1, с. 29-32].

Мета статті - дослідити процес виправлення під час відбування покарання у виді позбавлення волі як елемент прогресивної системи: деякі законодавчі проблеми.

Виклад основного матеріалу. У науці кримінально-виконавчого права та пенітенціарної педагогіки виправлення розглядається як результат комплексного впливу на особистість засудженого, яке перетворює його на безпечну для суспільства людину (моральне виправлення). Разом з тим ступінь виправлення конкретного засудженого завжди індивідуальний, отже, i досягнення мети виправлення може бути різним. Головне тут - змінити спотворені моральні орієнтації засудженого, що зумовлюють вчинення злочинів, на позитивні, соціально корисні.

Виправлення $\epsilon$ головною лінією кримінально-виконавчого законодавства, на зазначеному понятті базується більшість норм КВК України. Так своєю чергою глава 19 КВК України «Виховний вплив на засуджених до позбавлення волі» визначає наступні напрями виховного впливу: соціально-виховна робота із засудженими до позбавлення волі (ст. 123 КВК України); загальноосвітнє і професійно-технічне навчання засуджених до позбавлення волі ( ст. 125 КВК України); богослужіння і релігійні обряди в колоніях (128 КВК України); заходи заохочення, що застосовуються до осіб, позбавлених волі (ст.130 КВК України); заходи стягнення, що застосовуються до осіб, позбавлених волі (ст. 132 КВК України) [3]. Незважаючи на те, що кримінально-виконавчим законодавством на цей час загалом вироблені основні напрями (форми) виховного впливу на засуджених до позбавлення волі, їх зміст залишається дискусійним. Багато в чому це пов'язано з недоліками правового регулювання цієї сфери діяльності установ i органів кримінально-виконавчої системи, зокрема 3 нечіткістю та недосконалістю кримінально-виконавчого законодавства.

Виховний вплив на засуджених, як різнобічний i тонкий психолого-педагогічний засіб, схильний до правового регулювання в меншому ступені, ніж режим і праця, і вимагає розвитку в кримінально-виконавчому законодавстві. Рішення проблем, що виникають у кримінально-виконавчих установах під час здійснення виховного впливу на осіб, засуджених до позбавлення волі, відіграє величезну роль у виконанні завдань, поставлених кримінально-виконавчої системою, в зв'язку з чим зараз іде пошук нових напрямів (форм) здійснення виховного впливу на засуджених. Зокрема, вирішення проблемних питань відповідно до напрямів виховного впливу на засуджених до позбав- лення волі, які закріплені у кримінально-виконавчому законодавстві. Важливість удосконалення певних норм КВК України в частині напрямів виховного впливу на засуджених до позбавлення волі $є$ також актуальним тому, що саме через процес їх реалізації відтворюються певні елементи та форми прогресивної системи виконання та відбування покарання у виді позбавлення волі.

Пропонуємо проаналізувати деякі норми КВК України, які безпосередньо містять положення, які регламентують процес виправлення під час відбування покарання у виді позбавлення волі, що впливає на його поліпшення або погіршення становища під час відбування покарання у виді позбавлення волі та відтворює певні прояви прогресивної системи виконання, відбування покарання у виді позбавлення волі. Крім того, проведений аналіз зазначених норм може сприяти визначенню окремих проблем, які заважають досконалої їх реалізації.

Як вже зазначалося вище, КВК України містить окрему главу, яка встановлює положення щодо виховного впливу на засуджених до позбавлення волі. ч. 1 ст. 123 КВК України «Соціально-виховна робота із засудженими до позбавлення волі» соціально-виховною роботою визначає цілеспрямовану діяльність персоналу органів і установ виконання покарань та інших соціальних інституцій для досягнення мети виправлення і ресоціалізації засуджених. Соціально-виховна робота спрямована на формування та закріплення в засуджених прагнення до заняття суспільно корисною діяльністю, сумлінного ставлення до праці, дотримання вимог законів та інших прийнятих у суспільстві правил поведінки, підвищення їх загальноосвітнього і культурного рівнів. Ч. 2 ст. 123 КВК України йдеться про те, що участь засуджених у виховних заходах, які проводяться в колоніях, враховується під час визначення ступеня їхнього виправлення, а також під час застосування заходів заохочення або стягнення. Однак невизначеними залишаються механізм їх урахування, критерії тощо. Проблема в тому, що проконтролювати вказані положення дуже складно. А фактор добровільної участі засуджених у програмі власного самоудосконалення та зміни на краще взагалі не має конкретного визначення. Викликає певні міркування редакція ч. 4 ст. 123 КВК України, яка вказує на те, що «стимулювання правослухняної поведінки засуджених здійснюється за допомогою програм диференційованого виховного впливу з урахуванням їхної поведінки, психічного стану і ступеня соціальної занедбаності». У статті використовується поняття «стимулювання» - проте ніде не розкривається його зміст та сутність. Така редакція здається невдалою, якщо виходити із змісту та сутності таких категорій, як «стимулювання», «програма диференційованого виховного впливу». Звернемося до визначення понять «Стимул», «стимулювання», яке надається у словниках, «стимул»- спонукальна причина, поштовх; зацікавленість у вчиненні чого-небудь; «стимулювання: когось дати (давати) стимул до чого-небудь; створювати, давати стимул або бути стимулом до чого-небудь; прискорювати, посилювати, поліпшувати здійснення чого-небудь [4]. Отже, стимулювати - викликати бажання, готовність, прагнення до досягнення певних цілей, які відповідають законним правам та інтересам засудженої особи, в більш оптимальні терміни. 
В такому розумінні стимулювання $\epsilon$ засобом реалізації прогресивної системи виконання покарання. I механізм стимулювання $є$ досить різнобічним, якщо виходити із змісту КВК України.

Програма диференційованого виховного впливу - це перелік конкретних заходів щодо здійснення карально-виховного впливу на засуджену особу під час відбування покарання, який може змінюватися залежно від поведінки особи та відбутого терміну покарання. Складником цієї програми можуть бути певні засоби, механізми стимулювання до певної конкретної цілі, на певному конкретному етапі відбування покарання. Проте реалізація індивідуальної програми $є$ лише одним із елементів стимулювання.

Досить широкий та важливий процес стимулювання до правослухняної поведінки засудженої особи залежить від досить великої кількості складників, і не тільки від рівня соціально-виховної роботи. На наш погляд, визначенню поняття «стимулювання», його ознакам, механізму реалізації має бути присвячена окрема норма, де мають знайти своє місце (відображення) усі основні напрями та засоби досягнення мети виправлення та ресоціалізації засудженої особи через використання прогресивної системи виконання покарання.

Окремі статті Кримінально-виконавчого кодексу України визначають такий напрям виховного впливу на засуджених до позбавлення волі, як загальноосвітнє і професійно-технічне навчання засуджених. Так, статті 126 та 127 КВК України є важливими, оскільки загальноосвітнє і професійно-технічне навчання засуджених, участь засуджених у самодіяльних організаціях заохочується адміністрацією колонії і враховується під час визначення ступеня їхнього виправлення. Ці показники враховуються на двох рівнях - під час заохочення (в даному випадку цей термін використовується в вузькому значенні - можливим $є$ щомісячне заохочення нарахуванням додаткової суми на особистий рахунок, заохочення к святам тощо); під час визначення ступеня виправлення, що має значення у разі переведення як в межах установи, так і в іншу установу (в даному випадку це теж заохочення, але в більш широкому значенні). Отже, використовується поняття «заохочується», яке, на жаль, не розкривається за змістом та не має критеріїв співвідношення із поняттям «стимулювання».

Особливої уваги потребують положення статей 130, 131, 132 КВК України в частині реалізації напрямів виховного впливу на засуджених до позбавлення волі. У ч. 1 ст. 130 КВК України «Заходи заохочення, що застосовуються до осіб, позбавлених волі» йдеться про те, що «за сумлінну поведінку і ставлення до праці, навчання, активну участь у роботі самодіяльних організацій до засуджених можуть застосовуватися такі заходи заохочення»: подяка; дострокове зняття раніше накладеного стягнення; нагородження похвальною грамотою; присвоєння почесного звання «кращий за поведінкою», «активний учасник самодіяльності» тощо; виплата грошової премії; нагородження подарунком; переведення на поліпшені умови тримання; надання дозволу для виїзду за межі колонії з метою відвідування рідних до семи діб засудженим, які тримаються у дільницях соціальної реабілітації виправних колоній мінімального рівня безпеки із загальними умовами тримання та середнього рівня безпеки; надання додаткового короткострокового або тривалого побачення; дозвіл додатково витрачати гроші для придбання продуктів харчування і предметів першої потреби в сумі до п'ятдесяти відсотків мінімального розміру заробітної плати; збільшення тривалості прогулянки засудженим, які тримаються в дільницях посиленого контролю колоній і приміщеннях камерного типу виправних колоній максимального рівня безпеки, до двох годин. В ч. 2 ст. 130 КВК України йдеться: «Засуджені, які стали на шлях виправлення або сумлінною поведінкою і ставленням до праці довели своє виправлення, можуть бути у встановленому законом порядку представлені до заміни невідбутої частини покарання більш м'яким покаранням або до умовно-дострокового звільнення від відбування покарання». В статті використовується поняття «заходи заохочення», які застосовуються незалежно від відбутого строку. Проте слід враховувати, що факт заохочення у підсумку впливатиме на загальну оцінку поведінки особи та визначення ступеня виправлення у разі вирішення питання про зміну умов тримання шляхом переведення до дільниць чи в іншу установу. Отже, опосередковано ці норми, які регулюють напрями виховного впливу, є елементом прогресивної системи виконання покарання у виді позбавлення волі. Крім того, з зазначеного вбачається, що законодавець відносить інститути, передбачені ст. 81, 82 КК України, до заохочувальних заходів. Однак, до сьогодні триває дискусія щодо співвідношення умовно-дострокового звільнення та прогресивної системи.

Законодавцем окремо визначено такий вид стягнення, як «скасування поліпшених умов тримання, передбачених ст. ст. 138-140, 143 КВК України». Положенням щодо стягнення «скасування поліпшених умов тримання, передбачених ст.ст. 138-140, 143 КВК України», яке визначено в ст. 132 КВК України, на жаль, не визначено деяких положень у переліку заходів заохочення щодо поліпшених умов. Отже, виникає ряд запитань щодо місця цього заходу в системі стимулювання та заохочень, зокрема щодо визначення понять, ознак та видів.

$€$ певні недосконалості реалізації такої норми КВК України, як ст. 133 КВК України «Злісне порушення встановленого порядку відбування покарання». Вказана стаття надає достатньо чітке визначення, що визнається злісним порушенням встановленого порядку відбування покарання. Однак вказана стаття не використовується у КВК України по відношенню до зміни умов тримання. Тим самим не встановлюються правові наслідки визначення по відношенню до засудженого злісного порушення встановленого порядку відбування покарання. А також який понятійний апарат правильніше використовувати - «злісний порушник» чи «злісне порушення».

Висновки. Таким чином, виховний процес у кримінально-виконавчих установах - це важкий вид педагогічної діяльності, який включає в себе деякі відносно самостійні, хоча і взаємопов'язані елементи: вивчення особистості засудженого, вибір засобів, способів і форм впливу на нього, їх реалізацію, контроль за результатами. Прагнення зробити висновок про виправлення засудженого на основі лише окремих критеріїв, без урахування певних неточностей або взагалі невизначеностей у законодавстві, може призвести до грубих помилок. А безпосередні норми КВК України, а саме вдосконалення їх, може створити необхідні підстави для правильної їх реалізації та безпосереднього засто- 
сування у разі визначення виправлення засуджених під час відбування покарання у виді позбавлення волі. Проведений нами аналіз окремих норм КВК України надав підстав стверджувати, що КВК України містить достатню кількість норм, які визначають положення щодо напрямів реалізації виховного впливу. Однак деякі з них мають низку невирішених питань, які стосуються понятійного апарату; певні положення взагалі не знаходять свого втілення у процесі встановлення критеріїв виправлення. Отже, все це позначається на процесі їх реалізації та потребує негайного втручання з метою перегляду деяких норм та внесення змін до окремих норм у КВК України.

\section{Література}

1. Алексеев В.И. Российская пенитенциарная политика в середине XIX - начале XX в. Уголовно испол- нительная система: право, экономика, управление. 2010. № 5. С. 29-32.

2. Беляев Н.А. Уголовно-правовая политика и пути ее реализации. Л., 1986.176 с.

3. Кримінально-виконавчий кодекс України: чинне законодавство із змінами та доповн. на 03 вересня 2015 р.: (Офіц. текст). Київ : Алерта, 2015. 82 с.

4. Ожегов С.И., ШведоваН.Ю. Толковый словарь русского языка. 4-е изд., доп. Москва : 000 «А ТЕМП», 2006. 944 с.

5. Чучаев Александр Иванович. Цели наказания в советском уголовном праве : учеб. пособие / А. И. Чучаев ; [отв. ред. - д-р юрид. наук, проф. ... Москва : [б. и.], 1989. 83 C

Гритенко О. А., кандидат юридичних наук, доцент, завідувач кафедри кримінального права та кримінології Одеського державного університету внутрішніх справ 